\title{
Notes on distribution, host associations, and bionomics of Erythmelus klopomor Triapitsyn (Hymenoptera, Mymaridae), an egg parasitoid of lace bugs in Missouri, USA, with particular reference to its primary host Corythucha arcuata (Say) (Hemiptera, Tingidae)
}

\author{
B. Puttler, ${ }^{1}$ W.C. Bailey, ${ }^{1}$ S.V. Triapitsyn ${ }^{2}$ \\ ${ }^{1}$ Division of Plant Sciences (Entomology), University of Missouri, Columbia, MO; ${ }^{2}$ Department of \\ Entomology, Entomology Research Museum, University of California, Riverside, CA, USA
}

\begin{abstract}
The fairyfly Erythmelus klopomor Triapitsyn (Hymenoptera, Mymaridae) is an idiobiont, multivoltine egg parasitoid of lace bugs (Hemiptera, Tingidae). The parasitoid apparently reproduces thelytokously and at present is only known in the USA from 36 counties in Missouri, two in Illinois, four in Florida and one each in North Carolina and Maryland. At least a somewhat wider occurrence of the parasitoid is indicated because of the ease by which it has been reared from its primary host the oak lace bug, Corythucha arcuata (Say). It also has been reared in Missouri from the additional hosts $C$. cydoniae (Fitch), C. marmorata (Uhler), C. pergandei Heidemann, C. ciliata (Say), and also from Gargaphia solani Heidemann (a new host record). The parasitoid is short lived with an average life cycle of 14.5 days and
\end{abstract}

Correspondence: Serguei V. Triapitsyn, Department of Entomology, University of California, Riverside, CA 92521, USA.

Tel.: +1.951.827.7817 - Fax: +1.951.827.3086.

E-mail: serguei@ucr.edu

Key words: Mymaridae, Erythmelus klopomor, distribution, host association, lace bugs, Corythucha, classical biological control.

Acknowledgments: appreciation is expressed to R.L. Blinn, North Carolina State University, Raleigh for corroborating the identifications of the lace bug species. C.J. Starbuck, University of Missouri, Horticulture Department, Columbia aided in determining the plant species mentioned in the study. M.W. Gates, USDA, ARS, Systematic Entomology Laboratory, Washington, D.C. initially facilitated obtaining identification of the parasitoid by forwarding material to S.V. Triapitsyn. Thanks are also due to D.L. Hostetter for review of an earlier draft of the manuscript. This study is a contribution from the Missouri Agricultural Experiment Station.

Received for publication: 31 July 2013.

Revision received: 1 November 2013.

Accepted for publication: 11 December 2013.

(C) Copyright B. Puttler et al., 2014

Licensee PAGEPress, Italy

Journal of Entomological and Acarological Research 2014; 46:1857

doi:10.4081/jear.2014.1857

This article is distributed under the terms of the Creative Commons Attribution Noncommercial License (by-nc 3.0) which permits any noncommercial use, distribution, and reproduction in any medium, provided the original author(s) and source are credited. apparently overwinters as an adult. Erythmelus klopomor should be considered as a candidate classical biological control agent against the recently introduced $C$. arcuata in Bulgaria, northern Italy, Switzerland, and Turkey, and also possibly against the well-established invasive $C$. ciliata in Europe.

\section{Introduction}

Lace bugs (Hemiptera, Tingidae) are commonly found on a variety of ornamental shrubs, urban and forest trees, and weeds (Johnson \& Lyon, 1991; Horn et al., 1979) and at times may warrant control measures if only to enhance esthetics on their respective host plants. Natural enemies, primarily an array of predators (e.g. lacewings, Orius spp. minute pirate bugs, assassin bugs, and predacious mirid bugs), and unaccountable mortality of eggs are cited as factors contributing to reducing damage caused by lace bug species (Connell \& Beacher, 1947; Horn et al., 1983). Sheeley \& Yonke (1977) studied seven species of lace bugs in Missouri, USA, and found no evidence of parasitoids attacking any life stages of them. An exception was the egg parasitoid Anagrus takeyanus Gordh (Hymenoptera, Mymaridae) which parasitizes the azalea, Stephanitis pyrioides (Scott), and andromeda, $S$. takeyai Drake \& Maa, lace bugs in Connecticut, southeastern USA, and Japan (Balsdon et al., 1996; Gordh \& Dunbar, 1977; Tsukada, 1999). There are very few references on the species of egg parasitoids attacking lace bugs in the USA (Gordh, 1979; Huber, 1986). Huber (1986) and Triapitsyn (2003) reviewed the world literature on host associations of the egg parasitoids in the family Mymaridae and the genus Erythmelus Enock, respectively, and found the only references pertaining to their relationships with lace bugs were occasional species in the genera Anagrus Haliday or Erythmelus. These were recorded in all zoogeographical regions except the Nearctic where there are no other described species of Anagrus or Erythmelus associated with lace bugs with the exception of the previously mentioned A. takeyanus (Gordh \& Dunbar, 1977) and A. virginiae Triapitsyn \& Puttler (Puttler \& Triapitsyn, 2006). Yet an Erythmelus sp. was mentioned as being reared in the USA from the sycamore lace bug, Corythucha ciliata (Say), the hawthorn lace bug, $C$. cydoniae (Fitch), and $C$. floridana Heidemann (Horn et al., 1979; Horn et al., 1983; Triapitsyn, 2003).

On 25 July 2003 a lace bug determined (by B. Puttler and corroborated by R.L. Blinn) to be oak lace bug (OLB), Corythucha arcuata (Say), was found infesting a bur oak (Quercus macrocarpa Michaux) (Fagaceae) on the University of Missouri - Columbia (Boone Co.). Eggs were readily observed on the underside of leaves and a serendipitous collection (ca. 10 egg clusters) was made from which 12 and 13 days 
later ( 6 and 7 August) mymarid parasitoids emerged. An additional collection of OLB eggs on 31 July 2003 also produced parasitoids as did a collection of OLB eggs from Howard Co. on 6 August 2003 which yielded parasitoids four days later. One of the authors (S.V. Triapitsyn) determined the parasitoid as probably a new, previously undescribed species of Erythmelus, which somewhat resembled the Neotropical tingid egg parasitoid E. tingitiphagus (Soares), and subsequently described it as $E$. klopomor Triapitsyn (Triapitsyn et al., 2007). The Missouri specimens are identical to specimens of E. klopomor from Florida, North Carolina, and Maryland in the USA (Triapitsyn et al., 2007). Later, Peña et al. (2009) reported E. klopomor also as an egg parasitoid of the avocado lace bug, Pseudacysta perseae (Heidemann), in Florida.

Recoveries of the E. klopomor in Missouri and Illinois then represented new host records and distributions approximately 2000-2500 km from its other previously known locations (Table 1). Since a dearth of mymarid species host associations exists, an investigation of the parasitoid status in Missouri and elsewhere was undertaken.

\section{Materials and methods}

The University of Missouri Campus at Columbia, Missouri (UMC) (Boone Co.) and its Horticulture and AgroForestry Research Center (HARC) at New Franklin in Howard Co., both in central Missouri, were the major study sites. The UMC site is typical of an urban environment with a landscape of trees, shrubs, flowering plants, and weeds scattered throughout the campus. The HARC site is rural, consisting of an experimental plantation of a variety of trees and shrubs in the midst of an area of open fields, orchards, and pastures. Both sites harboured lace bugs with eight species present, seven Corythucha spp. and one Gargaphia sp., on their respective host plants which are listed in Table 2. In addition, the eggplant lace bug, Gargaphia solani Heidemann, was collected from horsenettle, Solanum carolinense L. (Solanaceae), at Concordia, Lafayette Co., Missouri.

In 2004 observations for OLB eggs located within the city of Columbia and at the HARC site began as trees leafed out in May and terminated by late September, when viable eggs were no longer present on host plants. In addition, one time surveys were conducted from June-September to determine distribution of the parasitoid E. klopomor from egg surveys collected from oak species (Table 2) at selected locations from 51 Missouri counties and 4 adjoining counties in Illinois (Table 1). Eggs from other lace bug species also were collected to delineate the potential host range of the parasitoid occurring in the study areas.

Sampling was performed visually on the various host plants by searching leaves that showed typical lace bug feeding, e.g. discoloration and whitening of the upper leaf surface (Connell \& Beacher, 1947). Depending on the observed severity of the lace bug infestation various numbers of leaves were collected from one to five plants at each collection site, placed in sealed plastic bags and returned to the laboratory where they were examined under the microscope to reliably distinguish between hatched and unhatched eggs. Two types of oviposition were characterized by lace bug species. The eggs of $C$. arcuata and $C$. cydoniae were laid in irregular clusters, readily visible, varying in numbers (ca. 10$100+$ ) and slightly embedded in leaf tissue, whereas, the eggs of $C$. ciliata and $C$. pergandei Heidemann were deeply embedded in pubescent leaf tissue along the veins, midribs, and secondary vein junctions and laid singularly or in groups of $<10$ (Barber \& Weiss, 1922).

Rearing of E. klopomor from samples collected at all locations and dates was accomplished by excising the leaf portion containing unhatched eggs and placing them on the surface of filter paper lined 100x150 mm Petri dishes. The egg masses were monitored daily for 21 days for egg parasitoid emergence with most adults removed daily. These observations provided a means of estimating the parasitoids' develop-
Table 1. Known distribution of the oak lace bug parasitoid Erythmelus klopomor from recoveries in Missouri and other states in the USA.

\begin{tabular}{|c|c|}
\hline State/County & Locality \\
\hline \multicolumn{2}{|l|}{ Missouri } \\
\hline Adair & Kirksville \\
\hline Audrain & Mexico \\
\hline Barton & Lamar \\
\hline Boone & Columbia \\
\hline Callaway & Fulton \\
\hline Cedar & Eldorado \\
\hline Clark & Kahoka \\
\hline Clay & Smithville \\
\hline Cole & Jefferson City \\
\hline Dade & Greenfield \\
\hline Dallas & Buffalo \\
\hline Franklin & Gray Summit \\
\hline Gasconade & Rosebud \\
\hline Gentry & Albany \\
\hline Henry & Clinton \\
\hline Howard & New Franklin \\
\hline Jackson & Blue Springs \\
\hline Jefferson & Eureka \\
\hline Johnson & Kingsville \\
\hline Knox & Edina \\
\hline Lafayette & Concordia \\
\hline Lawrence & Mt. Vernon \\
\hline Lewis & Lewiston \\
\hline Livingston & Burger \\
\hline Marion & Palmyra \\
\hline Monroe & Madison \\
\hline Pettis & Sedalia \\
\hline Polk & Humansville \\
\hline Ralls & New London \\
\hline Saline & Sweet Springs \\
\hline St. Charles & Weldon Springs \\
\hline St. Claire & Osceola \\
\hline St. Louis & St. Louis \\
\hline Vernon & Nevada \\
\hline Warren & Warrenton \\
\hline Worth & Grant City \\
\hline \multicolumn{2}{|l|}{ Illinois } \\
\hline Henderson & Gladstone \\
\hline Hancock & Nauvoo \\
\hline \multicolumn{2}{|l|}{ Florida } \\
\hline Broward & Pompano Bay \\
\hline Palm Beach & West Palm Beach \\
\hline Monroe & Islamorada \\
\hline Okeechobee & Fort Drum \\
\hline Osceola & Canoe Creek \\
\hline \multicolumn{2}{|l|}{ Maryland } \\
\hline Prince George & Greenbelt \\
\hline \multicolumn{2}{|l|}{ North Carolina } \\
\hline Wake & Raleigh \\
\hline
\end{tabular}


mental time from field collected eggs to adult emergence. A subsample of 15 emerged adults were placed in shell vials with and without a diluted honey food source to determine adult longevity under the rearing conditions described. In addition, a small number of adults were retained in Petri dish samples and observed under the microscope for ovipositional behavior when exposed to unparasitised lace bug eggs. These eggs were further monitored to determine the parasitoid life cycle from time of oviposition to adult emergence. Sample dishes were held in the laboratory where rearing conditions for both eggs and emerged adults ranged from $20-24^{\circ} \mathrm{C}$ with $8-10 \mathrm{~h}$. of daily light exposure during the week and total darkness on weekends at ca. 40-50\% R.H.

Voucher specimens of $E$. klopomor from this study are deposited in the collections of the Entomology Research Museum, University of California at Riverside, California, USA (UCRC) and W.R. Enns Entomological Museum, University of Missouri, Columbia, Missouri, USA (UMRM) (Triapitsyn et al., 2007), and those of its lace bug hosts in the UMRM.

\section{Results}

\section{Lace bug and plant host associations of Erythmelus klopomor}

At the HARC study site, $C$. arcuata eggs were first detected on bur oak on 10 May 2004. Egg samples collected on this date and monitored for adult parasitoid emergence did not yield parasitoids. From the next sample on 18 May and weekly samples thereafter, E. klopomor adults emerged from egg collections from each sampling date. The first adult parasitoids appeared on 2 June and the last on 27 September; 15 and 6 days post collection, respectively. Observations on bur oak at UMC deviated slightly. C. arcuata eggs were first seen and sampled on 12 May with subsequent collections on 21 and 27 May. No E. klopomor was reared from these collections. They were reared from each egg collection at this site starting 2 June and weekly thereafter till 1 October. The first parasitoid adults emerged on 11 June and were again present in each sample with the last emergence on 6 October, 9 and 5 days post collection, respectively. In both localities, minimum/maximum emergence times ranged from 1-17 days as per other collection dates with all variations in between. In 2004 the last parasitoids to emerge from the UMC bur oak samples of 1 and 3 October was 14 October. There were no apparent differences in the phenology of the OLB as to when the eggs were first observed at the study sites (10 versus 12 May). Yet there was a difference in first generation parasitoid emergence as E. klopomor appeared 9 days later at UMC than at HARC (11 versus 2 June).

At both UMC and HARC E. klopomor was reared from miscellaneous collections of $C$. arcuata infesting other oak species (Table 2). All of these oaks are referred to as white oak and the OLB is apparently specific to these oak species. Red oaks [e.g. Q. rubra Michaux (northern red oak), $Q$. palustris Muenchhausen (pin oak)] adjacent to and in close proximity to OLB infestations were never infested. E. klopomor also was reared

Table 2. Host plants of lace bugs (Tingidae) and those species serving as hosts for Erythmelus klopomor at the University of Missouri study sites.

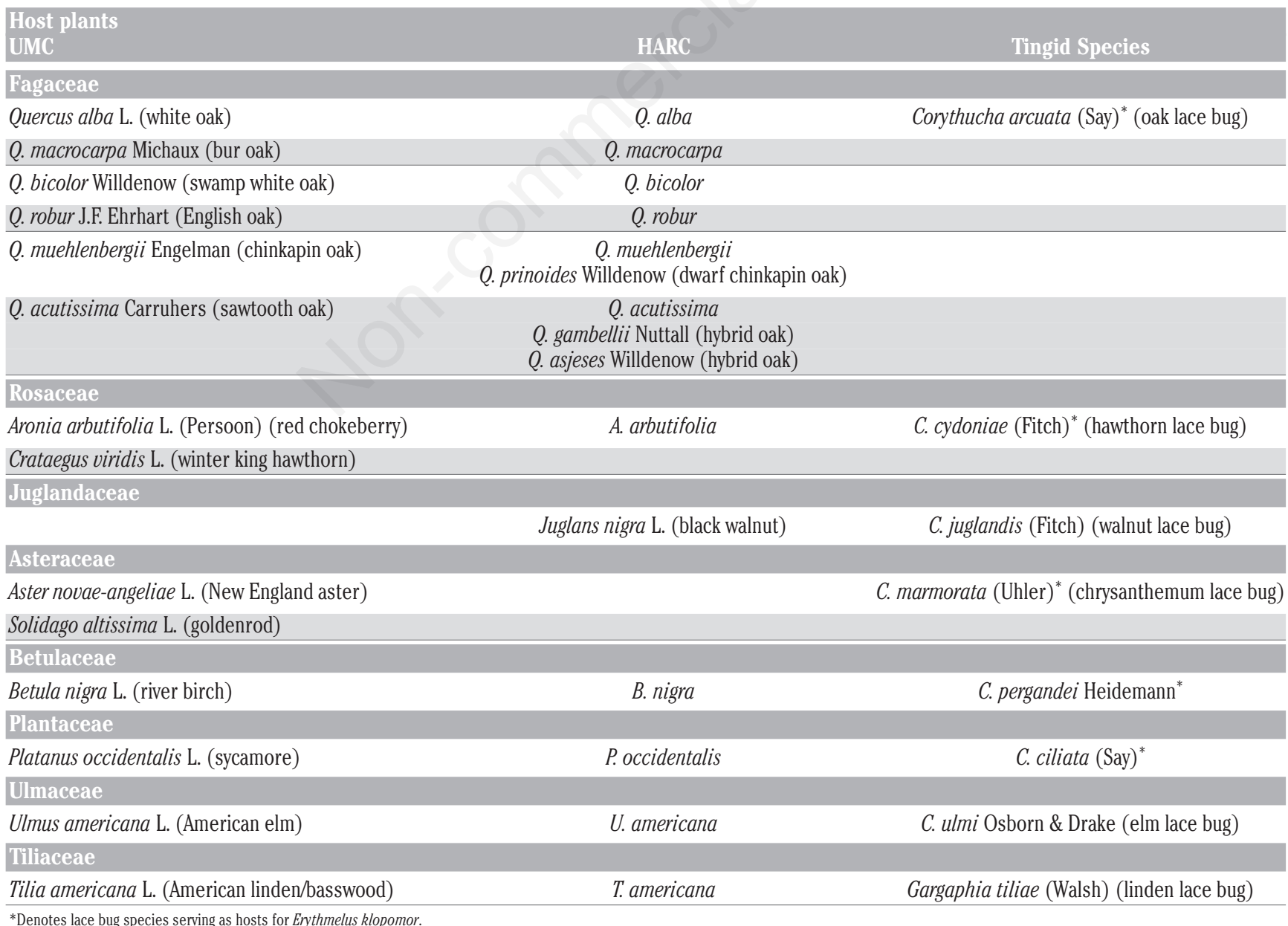


from $C$. cydoniae on Aronia arbutifolia L. (Rosaceae) at HARC, but not from C. ulmi Osborn \& Drake, C. ciliata, C. juglandis (Fitch) nor from Gargaphia tiliae (Walsh) at this locality. In contrast, all lace bug species at UMC except $G$. tiliae were hosts of E. klopomor (Table 2).

$E$. klopomor were reared from one-time collections of $C$. arcuata eggs in each of 36 Missouri counties (Figure 1, Table 1). Parasitoids were not detected in another 10 counties due to the absence of eggs and another 5 counties in which eggs yielded no parasitoids (Figure 1). We did recover parasitoids in two of four Illinois counties (Hancock Co. and Henderson Co.) from OLB on bur oak and these represent new Illinois state records as do our other samples for Missouri. The known hosts of E. klopomor at the study sites in Missouri are listed in Table 2.

\section{Biology of Erythmelus klopomor}

Based on our laboratory observations, E. klopomor is a solitary idiobiont parasitoid of lace bug eggs. It was found that unmated females produced females; therefore, the species apparently reproduces thelytokously even though occasional males are recorded (Triapitsyn et al., 2007). Newly emerged females do not undergo a preovipositional period and are capable of ovipositing on or shortly after emergence (proovigenic). The adults are readily attracted to egg clusters where the eggs are examined by antennal palpitation to determine their suitability for oviposition. Oviposition is apparently deterred if eggs are too far along in development or previously parasitized. No host feeding was observed. Acceptable eggs were mounted and the ovipositional act occurred via the ovipositor penetrating the egg through the rim of its operculum. The entire ovipositional procedure was completed in 3-5 min. The life cycle from egg to adult ranged from 11-17 days $(n=20$; mean of $14.15+0.4$ S.E.) under our rearing conditions and was ca. half the time (26-36 days) it took $A$. takeyanus to develop under similar rearing conditions (Balsdon et al., 1996). As per some other mymarid species, the parasitoid emerges by pushing out the operculum. It is short lived, with or without a food source. Longevity was usually $<48 \mathrm{~h}$ and was similar to that of $A$. takeyanus.

\section{Discussion and conclusions}

Five Corythucha spp. in Missouri (Table 2) plus G. solani (a new host record; eggs of this host had been collected in the same state but outside of the study sites, and these were successfully parasitized by $E$. klopomor when exposed in the laboratory), as well as $C$. floridana (Triapitsyn et al., 2007) and $P$. perseae (Peña et al., 2009), both in Florida, are recorded as hosts of $E$. klopomor. Based on our observa-

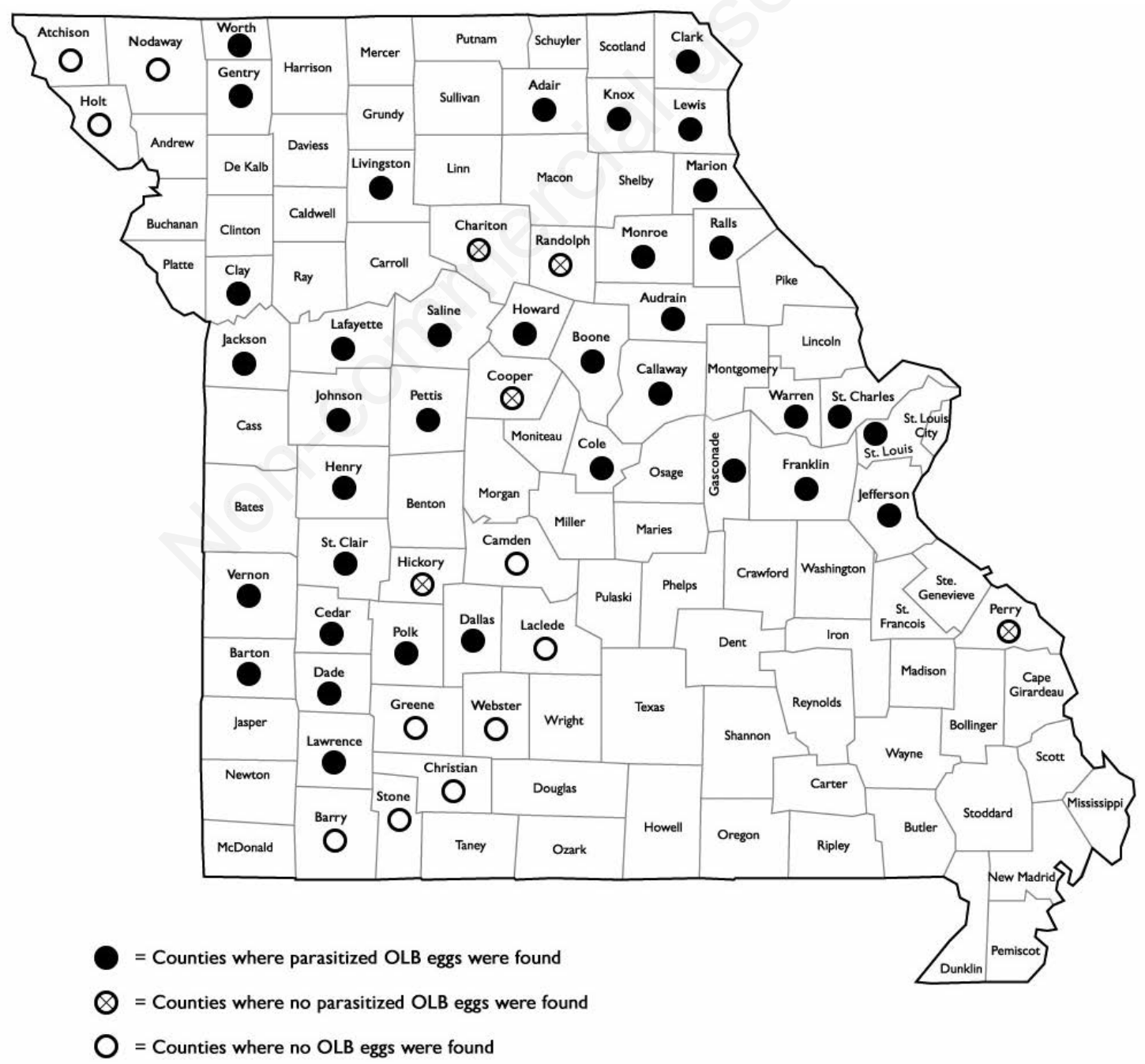

Figure 1. Distribution of Erythmelus klopomor in Missouri, USA. 
tions the parasitoid was most readily reared from $C$. arcuata because this species oviposits eggs that are more easily accessible to $E$. klopomor females (larger numbers/cluster) and not as deeply embedded in leaf tissue. Next in preference was $C$. cydoniae with all other lace bugs serving as incidental hosts.

The ease in which they were recovered from samples of $<10-30$ viable egg clusters per county is indicative of at least a somewhat wider distribution of $E$. klopomor within Missouri and other states; however, the species is not yet known from the western USA. This assumption is based on the parasitoid's known distribution within Missouri (Figure 1), Illinois (a new state record), Florida, Maryland, and North Carolina from eggs of $C$. ciliata and C. cydoniae (Horn et al., 1979; Horn et al., 1983; Triapitsyn et al., 2007). We predict that $E$. klopomor will eventually be found coincident with its primary hosts of $C$. arcuata and $C$. cydoniae since their distribution encompasses most of the USA as do their known insect hosts (Table 2) and related host plants (i.e. Quercus spp.).

Since all the known lace bug hosts of $E$. klopomor overwinter as adults (Barber \& Weiss, 1922) the question arises as how this short lived parasitoid survives year-to-year, from ca. October until the following May when no host eggs were found. We are of the opinion that it overwinters as a diapausing adult in secluded niches on its hosts' host plants (cracks and crevices in trunk and branches) or in nearby environments. The latter unfortunately cannot be duplicated under artificial conditions. Puttler et al. (1973) came to a similar conclusion with another mymarid Anaphes nigrellus Girault [as A. behmani Girault (Huber, 1992)] as did Anderson \& Paschke (1968) for Anaphes flavipes (Foerster). In contrast, A. takeyanus has a known overwintering stage (eggs) to maintain the species (Gordh \& Dunbar, 1977; Tsukada, 1999).

Corythucha arcuata has recently become an invasive species in parts of Europe and also in the Asian part of Turkey (Mutun et al., 2009). It was first detected in northern Italy in 2000 and subsequently found in Switzerland in 2002, Turkey in 2003, and the Balkan Peninsula (Bulgaria) in 2012 (Bernardinelli, 2000; Mutun, 2003; Forster et al., 2005; Dobreva et al., 2013). Should $C$. arcuata manifest itself as an oak pest in its present distribution and disperse throughout Europe as $C$. ciliata did on sycamore over the same area (Maceljski, 1986), E. klopomor could be useful as a candidate agent in a potential classical biological control program against this pest and also possibly against $C$. ciliata after an evaluation of the possibility that the parasitoid did not interfere with EU autochthonous lace bug species. The following considered parasitoid attributes could lend themselves to such a program: i) an apparently thelytokous reproduction; multivoltism, short life cycle (at least half that of its preferred host); ii) preference for $C$. arcuata; iii) occurs in temperate, Mediterranean, and subtropical climates; and iv) parasitoid is readily collectable in its country of origin (USA).

\section{References}

ANDERSON R.C., PASCHKE J.D., 1968 - The biology and ecology of Anaphes flavipes (Hymenoptera: Mymaridae) an exotic parasite of the cereal leaf beetle. - Ann. Entomol. Soc. Am. 61: 1-5.

BALSDON J.A., BRAMAN S.K, ESPELIE K.E., 1996 - Biology and ecology of Anagrus takeyanus (Hymenoptera: Mymaridae), an egg parasitoid of the azalea lace bug (Heteroptera: Tingidae). - Environ. Entomol. 25: 383-389.

BARBER H.B., WEISS H.B., 1922 - The lacebugs of New Jersey. - New Jersey Dept. Agr. Bur. Stat. Insp. Circ. 54: 3-24.

BERNARDINELLI I., 2000 - Distribution of the oak lace bug Corythucha arcuata (Say) in northern Italy (Heteroptera Tingidae). - Redia 83: 157-162.

CONNELL W.A., BEACHER J.H., 1947 - Life history and control of the oak lace bug. - Delaware Agr. Exp. Sta. Bull. 265: 5-28.

DOBREVA M., SIMOV N., GEORGIEV G., MIRCHEV P., GEORGIEVA M.,
2013 - First record of Corythucha arcuata (Say) (Heterotera: Tingidae) on the Balkan Peninsula. - Acta Zool. Bulg. 65: 409-412. FORSTER B., GIACALONE I., MORETTI M., DIOLI P., WERMELINGER B., 2005 - Die amerikanische Eichennetzwanze Corythucha arcuata (Say) (Heteroptera, Tingidae) hat die Südschweiz erreicht. - Mitt. Schweiz. Entomol. Ges. 78: 317-323.

GORDH G., 1979 - Superfamily Chalcidoidea. In: KROMBEIN K.V., HURD JR. P.D., SMITH D.R., BURKS B.D. (Eds), Catalog of Hymenoptera in America north of Mexico, Vol. 1, Symphyta and Apocrita (Parasitica). - Smithsonian Institution Press, Washington, D.C.: 743-1043.

GORDH G., DUNBAR D.M., 1977 - A new Anagrus important in the biological control of Stephanitis takeyai and a key to the North American species. - Florida Entomol. 60: 85-95.

HORN K.F., FARRIER M.H., WRIGHT C.G., 1983 - Some mortality factors affecting eggs of the sycamore lace bug, Corythucha ciliata (Say) (Hemiptera: Tingidae). - Ann. Entomol. Soc. Am. 76: 262-265.

HORN K.F., WRIGHT C.G., FARRIER M.H., 1979 - The lace bugs (Hemiptera: Tingidae) of North Carolina and their hosts. - North Carolina Agr. Exp. Sta. Tech. Bull. 257: 1-22.

HUBER J.T., 1986 - Systematics, biology, and hosts of the Mymaridae and Mymarommatidae (Insecta: Hymenoptera) 1758-1984. Entomography 4: 185-243.

HUBER J.T., 1992 - The subgenera, species groups, and synonyms of Anaphes (Hymenoptera: Mymaridae) with a review of the described Nearctic species of the fuscipennis group of Anaphes s.s. and the described species of Anaphes (Yungaburra). - Proc. Entomol. Soc. Ontario 123: 23-110.

JOHNSON W.T., LYON H.H., 1991 - Insects that feed on trees and shrubs ( $2^{\text {nd }}$ ed.). - Cornell University Press, Ithaca, New York: 560.

MACELJSKI M., 1986 - Current status of Corythucha ciliata in Europe. Bull. OEPP/EPPO 16: 621-624.

MUTUN S., 2003 - First report of the oak lace bug, Corythucha arcuata (Say, 1832) (Heteroptera: Tingidae) from Bolu, Turkey. - Israel J. Zool. 49: 323-324.

MUTUN S., CEYHAN Z., SÖZEN C., 2009 - Invasion by the oak lace bug, Corythucha arcuata (Say) (Heteroptera Tingidae), in Turkey. Turk. J. Zool. 33: 263-268.

PEÑA J.E., TRIAPITSYN S.V., LONG D., EVANS G.A., ROLTSCH W., 2009 - First record of Erythmelus klopomor (Hymenoptera: Mymaridae) as a parasitoid of the avocado lace bug, Pseudacysta perseae (Heteroptera: Tingidae). - Florida Entomol. 92: 394-395.

PUTTLER B., THEWKE S.E., WARNER R.E., 1973 - Bionomics of three Nearctic species, one new, of Hypera (Coleoptera: Curculionidae), and their parasitoids. - Ann. Entomol. Soc. Am. 66: 1299-1306.

PUTTLER B., TRIAPITSYN S.V., 2006 - A new species of Anagrus (Hymenoptera: Mymaridae) from Missouri (U.S.A.), egg parasitoid of Corythucha marmorata (Hemiptera: Tingidae) - Entomol. News 117: 25-30.

SHEELEY R.D., YONKE T.R., 1977 - Biological notes on seven species of Missouri tingids (Hemiptera: Tingidae). - J. Kansas Entomol. Soc. 50: $342-356$.

TRIAPITSYN S.V., 2003 - Review of the Mymaridae (Hymenoptera, Chalcidoidea) of Primorskii krai: genus Erythmelus Enock, with taxonomic notes of some extralimital species. - Far Eastern Entomol. 126: 1-44.

TRIAPITSYN S.V., BEREZOVSKIY V.V., HODDLE M.S., MORSE J.G., 2007 - A review of the Nearctic species of Erythmelus (Hymenoptera: Mymaridae), with a key and new additions to the New World fauna. - Zootaxa 1641: 1-64.

TSUKADA M., 1999 - Interpopulation variation of hibernal-aestival-diapause in the egg parasitoid wasp Anagrus takeyanus: adaptation to seasonal host-plant alteration of the tingid host, Stephanitis takeyai. - Entomol. Exp. Appl. 92: 37-43. 